\title{
INTERNALIZATION OF RELIGIOUS VALUES IN THE ISLAM PROGRAM TEACHER'S FAMILY EDUCATION OF HIGH SCHOOL AND HIGH VOCATIONAL SCHOOL MUHAMMADIYAH BANJARMASIN
}

\author{
Abd. Basir \\ Fakultas Tarbiyah dan Keguruan UIN Antasari Banjarmasin, Indonesia \\ basir1968@gmail.com \\ Abdul Rahman \\ SMK Muhammadiyah 3 Banjarmasin, Indonesia \\ abdurrahmanshi52@gmail.com
}

Accepted: 10-07-2020

\begin{abstract}
The purpose of this qualitative research was to understand how to internalize the values of Islam in the family of Islamic high school teachers and Muhammadiyah Vocational School teachers in Banjarmasin. The main data collection for this research was through in-depth interviews, observation and documents. Then proceed with the analysis process with a phenomenological approach. Based on the analysis, we found out that; First, parents as teachers of Islamic religion in high schools and vocational high schools in the city of Banjamasin are started by giving values of faith to God and morals in accordance with the religion and society where the family is located. Second, parents as teachers of Islamic religion face major challenges in providing education to their children, so they seek additional solutions to religious education through non-formal education namely religious schools or boarding schools with full learning systems. Third; Motivation of parents is encouraged to choose additional education through boarding school is inseparable from the encouragement of the character of the community and scholars in the city of Banjarmasin as a public figure who is successful in fostering the community.
\end{abstract}

Keywords: Internalization, Religious values, Family education

\section{Abstrak}

Penelitian kualitatif ini bertujuan untuk. memahami bagaimana guru-guru menginternalisasi nilainilai Islam dalam keluarga di sekolah menengah Islam SMK Muhammadiyah di Banjarmasin. Pengumpulan data utama untuk penelitian ini adalah melalui wawancara mendalam, observasi dan dokumen. Kemudian dilanjutkan dengan proses analisis dengan pendekatan fenomenologis. Berdasarkan analisis, ditemukan bahwa; Pertama, orang tua sebagai guru agama Islam di sekolah menengah dan sekolah menengah kejuruan di kota Banjamasin dimulai dengan memberikan nilainilai iman kepada Tuban dan moral yang sesuai dengan agama dan masyarakat tempat keluarga itu berada. Kedua, orang tua sebagai guru agama Islam menghadapi tantangan besar dalam memberikan pendidikan kepada anak-anak mereka, sehingga mereka mencari solusi tambahan untuk pendidikan agama melalui pendidikan non-formal yaitu sekolah agama atau sekolah berasrama dengan sistem pembelajaran penub. Ketiga; Motivasi orang tua didorong untuk memilih pendidikan tambahan 
melalui sekolah berasrama tidak terlepas dari dorongan karakter masyarakat dan ulama di kota Banjarmasin sebagai tokoh masyarakat yang berhasil membina masyarakat.

\section{Kata Kunci: Internalisasi, Nilai Relegius, Pendidikan Keluarga INTRODUCTION}

Education is first taken by children is in the family. The family has an important role in providing growth to children. However, along with the development of technology the role of educational institutions gradually experienced such a drastic change. Family education institutions that instill the values of faith have switched to material values. Research conducted by Aslan, ${ }^{1}$ that the values of educational institutions in the family in the current information age have shifted to material values, so that children born are not intended to go to the afterlife but are more worldly. The pattern of parenting gives more value to technology compared to religious values. ${ }^{2}$ Education in the family in Islam even though more emphasis on religious values than material, but along with the flow of technological change, the goals of educational institutions experiencing extraordinary shifts.

Education in the family modeled more on western education. For feminists, the role of family institutions must be minimized, because it can cause social inequality so that women are increasingly isolated. Feminists want no difference for men and women. As a result, the impact of feminist understanding is also happening in Indonesia, such as increasing divorce rates, infidelity, LGBT and other behavior. The purpose of marriage in Islam has gradually been misunderstood by the public. ${ }^{3}$ In Islam, marriage is something sacred and a divine goal, so that the matter of choosing a mate there are criteria that have been determined both in the Qur'an and in the Hadith.

According to Kamrani Buseri, ${ }^{4}$ before having family status, the most important thing is to choose a mate, because mate determines the character of the child later. A good match is seen from the religious criteria, because when a child is born, parents have instilled religious values in the child. When children grow up, children are internalized from the symbol values given by parents to their children. Internalization is the filtering of the values given to children, both negative and positive values. ${ }^{5}$ These values will later shape the character of the child, even though external values are caused by peer influence that has negative values, then it has no influence for the child concerned, including current technological developments.

${ }^{1}$ Aslan, "Pergeseran Nilai Di Masyarakat Perbatasan (Studi tentang Pendidikan dan Perubahan Sosial di Desa Temajuk Kalimantan Barat)" (Disertasi, Banjarmasin, UIN Antasari Banjarmasin, 2019), https://idr.uinantasari.ac.id/10997/.Aslan, Agus Setiawan, dan Hifza, "Peran Pendidikan dalam Merubah Karakter Masyarakat Dampak Akulturasi Budaya di Temajuk," FENOMENA 11, no. 1 (2019): 11-30.Aslan, "Pendidikan Remaja Dalam Keluarga Di Desa Merabuan, Kalimantan Barat (Perspektif Pendidikan Agama Islam)," Al-Banjari 16, no. 2 (2017): 99-112.

${ }^{2}$ Aslan, "Peran Pola Asuh Orangtua di Era Digital," Jurnal Studia Insania 7, no. 1 (2019): 20-34.

11.

3S. Muslikhati, Feminisme dan Pemberdayaan Perempuan dalam Timbangan Islam (Jakarta: Gema Insani, 2004),

${ }^{4}$ Kamrani Buseri, Pendidikan Keluarga Dalam Islam Dan Gagasan Implementasinya (Yogyakarta: Lanting Media Aksara Publishing House, 2010).Kamrani Buseri, Dasar, Asas dan Prinsip Pendidikan Islam (Banjarmasin: IAIN Antasari, 2014).

5Peter L. Berger and Thomas Luckhman, The Social Construction Of Reality, vol. 6 (England: Penguin Books, 1991). Lihat juga, Aslan, "Pergeseran Nilai Di Masyarakat Perbatasan (Studi tentang Pendidikan dan Perubahan Sosial di Desa Temajuk Kalimantan Barat)."Aslan dan Hifza, “The Community Of Temajuk Border Education Values Paradigm On The School," International Journal of Humanities, Religion and Social Science 4, no. 1 (2020): 13-20.

Nazhruna: Vol. 3 No 2, 2020 
Challenge after challenge in the world of education, so that television media technology is more successful than the education curriculum. ${ }^{6}$ This negative influence, for parents as they are unable to deny it, so various efforts are made to fend off negative values both from technology, peers and the influence of the child's environment. Duties and responsibilities of parents in finalizing their children, experience differences depending also on the education of parents, especially parents as civil servant teachers ${ }^{7}$.

Parents who work as teachers, especially teachers of religion certainly want their children to be as successful as themselves. In fact, better and more advanced than his parents so that his future is bright and does not become a burden on the minds of parents. Therefore, to launch increasingly sophisticated technological developments, environmental influences and peers, parents from an early age have given religious value to their children. In this case, the role of parents in providing education to children has a comparable greater challenge with technological developments. Moreover, parents who have become civil servants and work as religious teachers.

Parents have a dual function of duty to the family and also to the school. The dual function that parents have, as parents and also as teachers, is that not all orders are obeyed by children and also students of their children who have become their students. ${ }^{8}$ Many assume that parents have no obligation at all to their children and these obligations have been submitted to children in school. ${ }^{9}$ These theories are refuted by several theories of moral development of children, where parents are very important for the stages of moral development of children to children at adulthood. ${ }^{10}$ Stage of moral development of children through three stages, from childhood born, until adolescents have a very important role for parents in teaching positive values. ${ }^{11}$ To form positive values for parents with a dual profession, namely as parents and as teachers, even more so becoming a religious teacher has challenges that great for the education given by parents in the family. Parents are busy being a teacher by giving education to students when he becomes a teacher and giving education to their children when he becomes a father. Both figures with differences in place between home and school are very difficult to get used to the figure of when to be a father when at home and the figure of being a teacher at school. From this form of difference, the writer feels interested in wanting to see more about the education of the value of Islam to children for a teacher by having a dual function between a religious teacher and a father.

'Aslan, "Kurikulum Pendidikan Vs Kurikulum Sinetron," Khazanab: Jurnal Studi Islam dan Humaniora 14, no. 2 (2016): 135-148.

7 Muhammad Anas Ma`arif dan Ari Kartiko, "Fenomenologi Hukuman di Pesantren : Analisis Tata Tertib Santri Pondok Pesantren Daruttaqwa Gresik," Nadwa 12, no. 1 (22 Juni 2018): 181-96, https://doi.org/10.21580/nw.2018.12.1.1862.

${ }^{8}$ Rafael Raga Maran, Pengantar Logika (Jakarta: Grasindo, 2007).

9 Chairinniza Graha, Keberbasilan Anak Di Tangan Orang Tua: Panduan bagi Orang Tua untuk Memahami Perannya dalam Membantu Keberbasilan Pendidikan Anak (Jakarta: Elex Media Komputindo, 2007), 15.

10 Singgih D. Gunarsa, Psikologi Perkembangan (Jakarta: BPK Gunung Mulia, 1981), 6. Singgih D. Gunarsa dan Yulia Singgih D. Gunarsa, Psikologi Perkembangan Anak Dan Remaja, Cetakan Ke 13 (Jakarta: BPK Gunung Mulia, 2008).

${ }^{11}$ Lawrence Kohlberg, Stages of Moral Development as a Basis for Moral Education (Harvard University: Center for Moral Education, 1971). 


\section{METHOD}

This research was conducted on Islamic Religious Education teachers in the city of Banjarmasin at Muhammadiyah high school and vocational high school. The type in this study is a field with phenomenal nature. Data collected by observation, interview and documentation. ${ }^{12}$ The data analysis technique used is to examine problems in case cases to obtain accurate evidence. The subjects of this study were Banjarmasin PAI teachers, which consisted of Banjarmasin Muhammadiyah 1 and 2 High Schools, Banjarmasin Muhammadiyah 1, 2 and 3 Vocational Schools, with 5 teachers. Data analysis in this study used Miles and Huberman's theory, with three components, namely data reduction, data display and drawing and verifying conclusions.

The process of checking the validity of the data from this study consists of an extension of participation, perseverance from observation and triangulation. ${ }^{13}$ The intended participation of the author is to stay at the research location to find the desired data in accordance with the study of this research to the point of saturation. This means that the data sought is complete and what is desired from the data from the results of interviews and observations has answered all questions from this study. In fact, interview sources, both structured and unstructured interviews have answered with almost the same answers. Meanwhile, the perseverance of this research is patience for a researcher to get the desired source of the behavior and culture of the people concerned. Meanwhile, triangulation used in this study consisted of two, namely triangulation of sources and methods. Source triangulation is the researcher comparing the results of interviews and observations obtained. Then, compare the results of the interview with each other. What is sought is not the results of the interview, but why the differences from the interview. Method triangulisation is data collection which is carried out using different strategies, namely interviews, observation and documentation. This is done to check the validity of the data.

\section{RESULTS AND DISCUSSION}

The process of education in human life is inseparable from the mate selection period. In Islam to choose a mate, it contains several criteria, namely property, beauty and religion. The choice is in accordance with the mandate of the Prophet, through the hadith is based on religion. With a good religion owned by a woman and also a man, it has been ensured to have good morals. From this character, as the initial capital for parents in teaching Islamic education to their children. Because with a good religion and automatically also good morals, then choosing a partner that is not based solely on lust so that with beauty and good looks make men and women fall in love, but because religion chooses partners to use various kinds of rituals in religion, for example first prayer isthiharah, ask the opinions of parents, scholars, clerics and other opinions, then the couple went to the aisle level.

At the time of the aisle to sprinkle seeds to his wife, it is inseparable from Islamic principles so that the seeds planted are in accordance with what is expected of the parents. ${ }^{14}$

\footnotetext{
${ }^{12}$ Lexy J. Meleong, Metode Penelitian Kualitatif (Bandung: Remaja Rosdakarya, 2008), 60.

${ }_{13}$ M. Djunaidi Ghony \& Fauzan Almansur, Metodologi Penelitian Kualitatif (Jogjakarta: Ar-Ruzz Media, 2012), 321-22.

${ }^{14}$ Buseri, Pendidikan Keluarga Dalam Islam Dan Gagasan Implementasinya, 61.
} 
When the child seeds have become, then the child's education has begun, even though the parents basically do not know at all that the child has begun to interact with his mother. ${ }^{15}$ In fact, to ensure this so the study was conducted by Ubes Nur Islam, ${ }^{16}$ Herdina Indrijati and et al, ${ }^{17}$ F. Rene Van De Carr and Marc Lehrer, ${ }^{18}$ that the child is in the womb with educational results the good that is given by parents, it can increase brain intelligence, have strong beliefs and have good communication between fellow humans. Children in the womb are learning classes for children provided by parents. Parents must make the best use of the class, so that the initial process of education in the womb is also obtained by the child. Then, when the child is born, then the next process of parents provides education in the family.

Education in the family is the first and foremost education pursued by children. ${ }^{19}$ The family is a natural educational institution, in which the family is an institution formed by God himself, because the family is the desire of God as Adam and Hawa. ${ }^{20}$ At this time, the duties and responsibilities of parents are increasingly greater for the education given to their children, as well as a mandate from God in which the results of education given by parents will give effect to the character or behavior of children in the future.

The influence experienced by parents in the current information age, on the one hand has challenges and on the other hand has hope. The biggest challenge is the influence of information currently making children experience two periods with different times. This period is a period where children live in cyberspace and a period where children live in the real world, the world as it is. Yasraf Amir Piliang, ${ }^{21}$ gave the form of life in the experience of humans today, like a folded world, because to know the development of the world no longer needs to wait for time, but only with a cellphone so that the term is the world in the palm of the hand. Challenges like this make education in the family experience weaknesses, which can be seen from the high rate of divorce, infidelity that will later have an impact on education for children. ${ }^{22}$ Therefore, as parents in educating their children, it is necessary to pay attention to the types of parenting provided to children, in accordance with the time the child was born in this world. Type of good parenting is in accordance with the situation and condition of a child's psychology. Children when experiencing emotions, then as a parent is not fishing from these emotions but looking for problems why emotions arise. Of the little things that parents pay attention to, it results in a pattern of stages of moral development to children.

\footnotetext{
Insani, 2004).

${ }^{17}$ Herdina Indrijati dan dkk, Psikologi Perkembangan dan Pendidikan Anak Usia Dini: Sebuah Bunga Rampai (Prenada Media, 2017), 3.

${ }^{18}$ F. Rene Van De Carr dan Marc Lehrer, While You Are Expecting (Humanics Publishing Group, 1985).

${ }^{19}$ Fahd Salem Bahammam, Keluarga Dan Akblak Dalam Islam: Penjelasan Tentang Kedudukan Keluarga Dan Komposisinya Dalam Islam Juga Tentang Urgensi Akblak Mulia Dalam Kehidupan Seorang Muslim (Indonesia: Modern Guide, 2015).

20 Amos Neolaka, Landasan Pendidikan Dasar Pengenalan Diri Sendiri Menuju Perubahan Hidup: Edisi Pertama (Indonesia: Kencana, 2017), 57.

21 Yasraf Amir Piliang, Dunia Yang Telah Diliipat: Tamasya Melampaui Batas-Batas Kebudayaan (Bandung: Matahari, 2011). Mujiburrahman, Agama, Media Dan Imajinasi: Pandangan Sufisme Dan Ilmu Sosial Kontemporer, Cetakan 2 (Banjarmasin: Antasari Press, 2015).

22 Margyono Budhi M, Fungsi Keluarga Dalam Meningkatkan Sumber Daya Manusia Daerah Khusus Ibukota Jakarta (Jakarta-Indonesia: Direktorat Jenderal Kebudayaan, 1995).
}

${ }^{15}$ Haidar Putra Daulay, Pendidikan Islam Dalam Perspektif Filsafat (Yogyakarta: Kencana, 2014), 116.

16 Ubes Nur Islam, Mendidik. Anak Dalam Kandungan: Optimalisasi Potensi Anak Sejak Dini Jakarta: Gema 
The difference between children born from one generation to another makes children live in different generations and the challenges experienced by parents are also different. In fact, a typical education in schools obtained by children, also experience differences. In this case, the curriculum underwent changes which currently have experienced ten times the old order, the new order and the reform order, so that the results of this study have been conducted research by Aslan and Wahyudin, ${ }^{23}$ about the curriculum in the challenge of change. The curriculum changes because there is a change of minister only as a mere symbol, but the change in the curriculum is to face the challenges of the times, so the hidden curriculum needs to be taught by teachers to their students. ${ }^{24}$ Curriculum faced by parents in teaching Islamic education to their children.

The education curriculum in the family is not as strict as the education in the school. ${ }^{25}$ Material taught by parents to their children through interaction does not have a program like the program in school. ${ }^{26}$ One parent with another parent. ${ }^{27}$ However, as Muslims must know about the values of education provided to children is inseparable from positive values. Positive values taught are not only limited to symbols of value, but rather symbols of meaning.

Symbols of meaning as observers of anthropology such as Clifford Geertz, ${ }^{28}$ that the meaning is something that can be interpreted and the interpreter is the parents themselves. These meanings have goals and expectations in the future given by parents to children, so that internalization of the values given will be a value for the lives of children, values become the child's guidelines and values for children to behave. In community life it is known as the norm value.

Internalization are symbols given by parents to children so that these symbols become references and guidelines for children. Internalization of the notions conceived by Peter L. Berger and Thomas Luckhman, ${ }^{29}$ has been given an understanding simple by Mujiburrahman, ${ }^{30}$ but in the concept of school, which children will get used to every day when there will be a ceremony. This internalization theory was again used in Aslan, ${ }^{31}$ research,

${ }^{23}$ Aslan dan Wahyudin, Kurikulum dalam Tantangan Perubahan (Medan: Bookies Indonesia, 2020).

${ }^{24}$ Aslan, Hidden Curriculum (Jawa Tengah: Pena Indis, 2019).

25 Amirulloh Syarbini, Model Pendidikan Karakter Dalam Keluarga (Jakarta: Elex Media Komputindo, 2014). 57.

${ }^{26}$ Lismina, PENGEMBANGAN KURIKULUM (Indonesia: Uwais Inspirasi Indonesia, 2017), 4.

${ }^{27}$ Mansur, Pendidikan Anak Usia Dini dalam Islam (Yogyakarta: Pustaka Pelajar, 2005), 12.M.S. Jailani, "Teori Pendidikan Keluarga dan Tanggung Jawab Orang Tua dalam Pendidikan Anak Usia Dini," Jurnal Nadwa 8, no. 2 (2014): 245-60.H. Langgulung, Manusia dan Pendidikan Suatu Analisis Psikologi dan Pendidikan (Jakarta: Pustaka al-Husna Zikra, 1986), 346.A. Basir, Model Pendidikan Keluarga Qur'ani (Studi Ali Imran dan Luqman) (Banjarmasin: Aswaja, 2015).

${ }^{28}$ Clifford Geertz, The Interpretation Of Cultures (New York: Basic Books, Inc., Publisher, 1973). Aslan dkk., "Paradigma Baru Tradisi 'Antar Ajung' Pada Masyarakat Paloh, Kabupaten Sambas," IBD A : Jurnal Kajian Islam Dan Budaya 18, no. 1 (29 April 2020): 87-103, https://doi.org/10.24090/ibda.v18i1.3354.

${ }_{29}$ Peter L. Berger and Thomas Luckhman, The Social Construction Of Reality. Peter L Berger, The Sacred Canopy: Elements Of a Sociological Theory Of Religion (Garden City, New York: Doubleday \& Company, Inc, 1967).

${ }_{30}$ Mujiburrahman, Bercermin Ke Barat: Pendidikan Islam Antara Ajaran dan Kenyataan, Cetakan Pertama (Banjarmasin: Jendela, 2013).

31 Aslan, "Pergeseran Nilai Di Masyarakat Perbatasan (Studi tentang Pendidikan dan Perubahan Sosial di Desa Temajuk Kalimantan Barat)." Aslan dan Agus Setiawan, "INTERNALIZATION OF VALUE

Nazhruna: Vol. 3 No 2, 2020 
which was not only carried out in schools but also in families. The values given in the family as Muslims are inseparable from the values of belief, monotheism and moral values. ${ }^{32}$ These values taught by parents are not only limited to the duties and responsibilities of parents but these values become habitual values and positive values that are shape the character of a child. For example, parents who always teach to go to the mosque together when the call to prayer echoes, then the process teaches children to get used to it. When the call to prayer echoes, then the children are accustomed to going to the mosque without the need to be invited by parents. This important value needs to be taught to be internalized or filtered by children so that it becomes a value in their lives.

Value and character will not be formed, if not first instilled a value for the child, so Thomas Lickona, ${ }^{33}$ gives a parable with a piece of wood will not be of high value if it does not have a carved value. Meanwhile, a child will have a high value if the character of his personality has positive morals. Therefore, to have a positive character will not be achieved and succeed if there are no duties and responsibilities of parents.

The process of internalization like this is carried out by PAI high school and vocational high school teachers in the city of Banjarmasin to their children. The values taught are the values of belief, monotheism and moral values. ${ }^{34}$ The value of the beliefs of the religion of Islam that is taught aims to be a servant of God who has faith and is devoted to being a pious and shalehah child. ${ }^{35}$ While the value of monotheism is the intrumental value in human life. In Islamic education to children, the value of monotheism is imbued with norms divine as well as a motivational value in worship so that something that is done has a worship value that is not only from the material aspect but has a spiritual aspect. ${ }^{36}$ Meanwhile, moral values are the value of guidelines that are prevented from doing negative actions. ${ }^{37}$ When children do negative actions, then the heart there will be an obstacle to doing the act. Values become a barometer in his life.

The results of interviews conducted with Zakiah $S,{ }^{38}$ that the value of the belief given to her child is the initial foundation for the child's faith. Then, the value of monotheism as a value to introduce to children something that is allowed and prohibited in the teachings of Islam. Furthermore, moral values are something that is taught to children from negative and positive things to be known by children, so to do something that is contrary to their conscience then the child feels guilty. The teachings taught by parents of moral values as a barrier to doing negative things. The category of teaching taught by parents to children in the city of Banjarmasin with a strong religious influence from the teachings of the Ulama so that this value becomes the main value of the education provided by parents in Banjarmasin. In

EDUCATION IN TEMAJUK-MELANO MALAYSIA BORDER SCHOOL," Edukasia: Jurnal Penelitian Pendidikan Islam 14, no. 2 (10 Desember 2019): 419-36, https://doi.org/10.21043/edukasia.v14i2.6031.

32 Basir, Model Pendidikan Keluarga Qur'ani (Studi Ali Imran dan Luqman).

33 Thomas Lickona, Educating For Character: Mendidik Untuk Membentuk Karakter, terj. Juma Abdu Wamaungo (Jakarta: Bumi Aksara, 2012).

${ }^{34}$ Wawancara dengan Zakiah, Pentingnya nilai kemanusiaan kepada anak dalam keluarga, 2019.

${ }^{35}$ Hasbi Indra, Pendidikan Keluarga Islam Membangun Generasi Unggul (Yogyakarta: Deepublish, 2017), 209.

36 Abuddin Nata, Pendidikan dalam Perspektif Al-Qur'an (Jakarta: Prenada Media, 2016).

37 Ali Abdul Halim Mahmud, Karakteristik Umat Terbaik: Telaah Manhaj, Akidah dan Harakah (Jakarta: Gema Insani, 1996), 114.

${ }^{38}$ Wawancara dengan Zakiah S, Nilai kemanusiaan dalam keluarga, 2019. 
fact, as religious teachers pay attention to formal educational institutions to their children to provide education that is Islamic.

Based on the author's observations when carrying out research, that this is done by parents as well as teachers who have a dual task, namely as parents and also as teachers who have the same goals as the goals of parents in general. Busy teaching from morning to evening so that it has limitations to interact with children. When they finish teaching and return from home by evening, the parents just rest, while their children play with their friends. When it was night, only a few hours met with the child and interacted but afterwards each of them took a break. Initiatives like this make parents as teachers find solutions so that religious values not taught by parents will be taught in schools that have Islamic status. The first and foremost value is value belief in values in Islam, then other values also refer to the value of religion that is believed, namely Islam, for example moral values.

According to Ramadhani $\mathrm{R},{ }^{39}$ the value taught to children is to introduce the value of laudable and ignoble morality. Commendable moral values are taught how to build a relationship with God, Allah's unity, piety, prayer and resignation taught through prayer in congregation, reading the Koran, giving and others. Meanwhile, according to Lismiati, ${ }^{40}$ values of faith are instilled in children through songs about the law of faith and Islam. The process of teaching religious values, beliefs and morals by parents even though they have safety but on the one hand have differences from the characteristics of the parents concerned.

Almost overall, PAI teachers in Banjarmasin city in giving first and foremost values to their children are inseparable from the values of creed, faith and sharia which are introduced in the same way but with different teaching methods. The goal is also the same, namely to introduce God in the constructivism of thinking children so that if children grow up, these values become values in children. ${ }^{41}$ However, inculcation of religious values in children, experiencing obstacles in the current information age. The more technology develops, the greater the challenges of family education institutions.

According to Alfin Toffler, ${ }^{42}$ change experienced by society today has experienced such a large change with such a short time. From the agricultural, industrial and present times, ${ }^{43}$ namely information technology. ${ }^{44}$ Tri education centers, both families, schools and communities experience great challenges, especially those experienced by PAI high school teachers and SMK Muhammadiyah Banjarmasin, on the one hand being parents and on the other hand become a teacher. Both of these roles so that Banjarmasin religious teachers in instilling religious values in their children have both supporting and inhibiting factors. Supporting factors of the success of Banjarmasin PAI teachers as parents in providing religious values to their children; First, high dedication. Parents as religious teachers in Banjarmasin turned out have a high dedication to their children in providing religious

${ }^{39}$ Wawancara dengan Ramadhani R, Internalisasi nilai dalam keluarga, 2019.

${ }^{40}$ Wawancara dengan Lismiati, Menanamkan nilai keimanan kepada anak dalam keluarga, 2019.

${ }^{41}$ M. Qurthubi, Penanaman Nilai Agama Kepada anak dalam keluarga, 2019. Wawancara dengan Sa'diah L, Penanaman Nilai Tauhid Kepada Anak dalam Keluarga, 2019.

${ }^{42}$ Alvin Toffler, Future Shock (New York: Bantam Books, 1970), 1-3.

${ }^{43}$ Alvin Toffler, The Third Wave (New York: William Morrow and Company, INC, 1980).

${ }^{44}$ Mujiburrahman, Humor, Perempuan dan Sufi (Jakarta: Kompas, Gramedia, 2017). 
education. Second, creating a religious atmosphere, both in the household and the environment around the house, for example near a mosque, surau or praying room.

\section{CONCLUSION}

First and foremost education for children is education in the family. Education in each family in each family has a different system of coaching to their children. However, for parents as well as religious teachers in the city of Banjarmasin in providing education in the family experience similarities, which values are the value of belief, the value of monotheism and moral values. However, the values given by Banjarmasin parents experience various obstacles, including having a dual role as a teacher and also as a parent, the influence of technology, peers and the environment. Therefore, parents find other solutions so that these influences can be overcome by providing Islamic education such as Islamic boarding schools to their children with a full day school system.

\section{REFERENCES}

Aslan. Hidden Curriculum. Jawa Tengah: Pena Indis, 2019.

. "Kurikulum Pendidikan Vs Kurikulum Sinetron." Khazanah: Jurnal Studi Islam dan Humaniora 14, no. 2 (2016): 135-148.

. "Pendidikan Remaja Dalam Keluarga Di Desa Merabuan, Kalimantan Barat (Perspektif Pendidikan Agama Islam)." Al-Banjari 16, no. 2 (2017): 99-112.

. "Peran Pola Asuh Orangtua di Era Digital." Jurnal Studia Insania 7, no. 1 (2019): 2034.

- "Pergeseran Nilai Di Masyarakat Perbatasan (Studi tentang Pendidikan dan Perubahan Sosial di Desa Temajuk Kalimantan Barat)." Disertasi, UIN Antasari Banjarmasin, 2019. https://idr.uin-antasari.ac.id/10997/.

Aslan, dan Hifza. "The Community Of Temajuk Border Education Values Paradigm On The School." International Journal of Humanities, Religion and Social Science 4, no. 1 (2020): 1320.

Aslan, dan Agus Setiawan. "INTERNALIZATION OF VALUE EDUCATION IN TEMAJUK-MELANO MALAYSIA BORDER SCHOOL.” Edukasia: Jurnal Penelitian Pendidikan Islam 14, no. 2 (10 Desember 2019): 419-36. https://doi.org/10.21043/edukasia.v14i2.6031.

Aslan, Agus Setiawan, dan Hifza. "Peran Pendidikan dalam Merubah Karakter Masyarakat Dampak Akulturasi Budaya di Temajuk.” FENOMENA 11, no. 1 (2019): 11-30.

Aslan, Nahot Tua Parlindungan Sihaloho, Iman Hikmat Nugraha, Budi Karyanto, dan Zukhriyan Zakaria. "Paradigma Baru Tradisi 'Antar Ajung' Pada Masyarakat Paloh, Kabupaten Sambas.” IBDA : Jurnal Kajian Islam Dan Budaya 18, no. 1 (29 April 2020): 87-103. https://doi.org/10.24090/ibda.v18i1.3354.

Aslan, dan Wahyudin. Kurikulum dalam Tantangan Perubahan. Medan: Bookies Indonesia, 2020.

Bahammam, Fahd Salem. Keluarga Dan Akblak Dalam Islam: Penjelasan Tentang Kedudukan Keluarga Dan Komposisinya Dalam Islam Juga Tentang Urgensi Akblak Mulia Dalam Kehidupan Seorang Muslim. Indonesia: Modern Guide, 2015. 
Abd. Basir, Abdul Rahman

Basir, A. Model Pendidikan Keluarga Qur'ani (Studi Ali Imran dan Luqman). Banjarmasin: Aswaja, 2015.

Berger, Peter L. The Sacred Canopy: Elements Of a Sociological Theory Of Religion. Garden City, New York: Doubleday \& Company, Inc, 1967.

Budhi M, Margyono. Fungsi Keluarga Dalam Meningkatkan Sumber Daya Manusia Daerah Khusus Ibukota Jakarta. Jakarta-Indonesia: Direktorat Jenderal Kebudayaan, 1995.

Buseri, Kamrani. Dasar, Asas dan Prinsip Pendidikan Islam. Banjarmasin: IAIN Antasari, 2014. . Pendidikan Keluarga Dalam Islam Dan Gagasan Implementasinya. Yogyakarta: Lanting Media Aksara Publishing House, 2010.

Carr, F. Rene Van De, dan Marc Lehrer. While You Are Expecting. Humanics Publishing Group, 1985.

Daulay, Haidar Putra. Pendidikan Islam Dalam Perspektif Filsafat. Yogyakarta: Kencana, 2014.

Geertz, Clifford. The Interpretation Of Cultures. New York: Basic Books, Inc., Publisher, 1973.

Graha, Chairinniza. Keberbasilan Anak Di Tangan Orang Tua: Panduan bagi Orang Tua untuk Memahami Perannya dalam Membantu Keberhasilan Pendidikan Anak. Jakarta: Elex Media Komputindo, 2007.

Gunarsa, Singgih D. Psikologi Perkembangan. Jakarta: BPK Gunung Mulia, 1981.

Indra, Hasbi. Pendidikan Keluarga Islam Membangun Generasi Unggul. Yogyakarta: Deepublish, 2017.

Indrijati, Herdina, dan dkk. Psikologi Perkembangan dan Pendidikan Anak Usia Dini: Sebuah Bunga Rampai. Prenada Media, 2017.

Islam, Ubes Nur. Mendidik Anak Dalam Kandungan: Optimalisasi Potensi Anak Sejak Dini. Jakarta: Gema Insani, 2004.

Jailani, M.S. "Teori Pendidikan Keluarga dan Tanggung Jawab Orang Tua dalam Pendidikan Anak Usia Dini." Jurnal Nadwa 8, no. 2 (2014): 245-60.

Kohlberg, Lawrence. Stages of Moral Development as a Basis for Moral Education. Harvard University: Center for Moral Education, 1971.

Langgulung, H. Manusia dan Pendidikan Suatu Analisis Psikologi dan Pendidikan. Jakarta: Pustaka al-Husna Zikra, 1986.

Lickona, Thomas. Educating For Character: Mendidik Untuk. Membentuk Karakter, terj. Juma Abdu Wamaungo. Jakarta: Bumi Aksara, 2012.

Lismina. PENGEMBANGAN KURIKULUM. Indonesia: Uwais Inspirasi Indonesia, 2017.

M. Djunaidi Ghony \& Fauzan Almansur. Metodologi Penelitian Kualitatif. Jogjakarta: Ar-Ruzz Media, 2012.

M. Qurthubi. Penanaman Nilai Agama Kepada anak dalam keluarga, 2019.

Ma`arif, Muhammad Anas, dan Ari Kartiko. "Fenomenologi Hukuman di Pesantren : Analisis Tata Tertib Santri Pondok Pesantren Daruttaqwa Gresik." Nadwa 12, no. 1 (22 Juni 2018): 181-96. https://doi.org/10.21580/nw.2018.12.1.1862.

Mahmud, Ali Abdul Halim. Karakteristik Umat Terbaik: Telaab Manhaj, Akidah dan Harakah. Jakarta: Gema Insani, 1996.

Mansur. Pendidikan Anak. Usia Dini dalam Islam. Yogyakarta: Pustaka Pelajar, 2005.

Maran, Rafael Raga. Pengantar Logika. Jakarta: Grasindo, 2007.

Meleong, Lexy J. Metode Penelitian Kualitatif. Bandung: Remaja Rosdakarya, 2008.

Nazhruna: Vol. 3 No 2, 2020 
Mujiburrahman. Agama, Media Dan Imajinasi: Pandangan Sufisme Dan Ilmu Sosial Kontemporer. Cetakan 2. Banjarmasin: Antasari Press, 2015.

- Bercermin Ke Barat: Pendidikan Islam Antara Ajaran dan Kenyataan. Cetakan Pertama. Banjarmasin: Jendela, 2013.

. Humor, Perempuan dan Sufi. Jakarta: Kompas, Gramedia, 2017.

Muslikhati, S. Feminisme dan Pemberdayaan Perempuan dalam Timbangan Islam. Jakarta: Gema Insani, 2004.

Nata, Abuddin. Pendidikan dalam Perspektif Al-Qur'an. Jakarta: Prenada Media, 2016.

Neolaka, Amos. Landasan Pendidikan Dasar Pengenalan Diri Sendiri Menuju Perubahan Hidup: Edisi Pertama. Indonesia: Kencana, 2017.

Peter L. Berger and Thomas Luckhman. The Social Construction Of Reality. Vol. 6. England: Penguin Books, 1991.

Piliang, Yasraf Amir. Dunia Yang Telah Dilïpat: Tamasya Melampaui Batas-Batas Kebudayaan. Bandung: Matahari, 2011.

Singgih D. Gunarsa dan Yulia Singgih D. Gunarsa. Psikologi Perkembangan Anak Dan Remaja. Cetakan Ke 13. Jakarta: BPK Gunung Mulia, 2008.

Syarbini, Amirulloh. Model Pendidikan Karakter Dalam Keluarga. Jakarta: Elex Media Komputindo, 2014.

Toffler, Alvin. Future Shock. New York: Bantam Books, 1970.

—. The Third Wave. New York: William Morrow and Company, INC, 1980.

Wawancara dengan Lismiati. Menanamkan nilai keimanan kepada anak dalam keluarga, 2019.

Wawancara dengan Ramadhani R. Internalisasi nilai dalam keluarga, 2019.

Wawancara dengan Sa'diah L. Penanaman Nilai Tauhid Kepada Anak dalam Keluarga, 2019.

Wawancara dengan Zakiah. Pentingnya nilai kemanusiaan kepada anak dalam keluarga, 2019.

Wawancara dengan Zakiah S. Nilai kemanusiaan dalam keluarga, 2019. 